\title{
Erythrocyte autoantibodies, autoimmune haemolysis, and carcinoma
}

\author{
R J Sokol, D J Booker, R Stamps
}

\begin{abstract}
Aims-To examine a large series of patients in whom both red cell autoantibodies and carcinoma are present; and to determine whether this rare occurrence is a true association or a chance event. Methods-The laboratory records of 160 patients ( 76 men, 84 women; mean age 68 years) with erythrocyte autoantibodies and confirmed carcinoma were examined for site of tumour origin and clinical and immunohaematological findings. To test whether the concomitant occurrence of autoantibodies and carcinoma was fortuitous, data on total population and carcinoma incidence were included in a $\chi^{2}$ analysis.
\end{abstract}

Results-The association was significant $\left(\chi^{2}=97.5, \mathrm{p}<0.0005\right)$; erythrocyte autoantibodies and carcinoma were found together 12-13 times more often than expected from their relative frequencies. Autoantibodies occurred with a variety of carcinomas, particularly those of breast, lung, colon, rectum, and prostate; this largely reflected tumour incidence. Adenocarcinoma, squamous, anaplastic, and transitional cell types were all represented. Warm, cold, and mixed autoantibodies were not associated with particular tumour sites or histology. Eighty six patients had haemolysis of varying severity, 37 had metastatic disease, and 28 died within a few months of presentation.

Conclusions-The presence of erythrocyte autoantibodies and carcinoma in the same patient is a true association and probably reflects a fundamental disturbance in immune homeostasis. It tends to occur with a large tumour mass and metastatic disease, and generally indicates a poor prognosis.

(F Clin Pathol 1994;47:340-343)

Studies of patients with autoimmune haemolysis, over a period of some 28 years, showed that $5-6 \%$ of cases also had non-ovarian carcinomas. ${ }^{12}$ In a review of 300 people with bronchogenic carcinoma seen over 10 years, two had concomitant autoimmune haemolytic anaemia, ${ }^{3}$ but in another series of 280 consecutive patients with lung cancer no cases of autoimmune haemolytic anaemia were found. ${ }^{4}$ The presence of both autoimmune haemolysis and carcinoma in the same subject is therefore uncommon and the question arises as to whether it is a true association, ${ }^{2}$ and the development of the two conditions is related, or whether it is a chance event. The Trent Regional Blood Transfusion Centre is in a unique position to study a comparatively large series of such cases as it provides a serological reference service for roughly 4.7 million people living in an area of about $16800 \mathrm{~km}^{2}$. $^{1}$ We describe in the present study those patients with both erythrocyte autoantibodies and carcinoma who have been referred to us since 1982; the number was sufficiently large for the validity of the association to be examined statistically.

\section{Methods}

A review was carried out of all cases seen in the immunohaematology department between 1 January 1982 and 30 September 1992. The records of patients with erythrocyte autoantibodies and a confirmed diagnosis of carcinoma were selected and critically examined. In all instances samples had been sent because of suspected autoimmune haemolytic anaemia or because autoantibodies were causing considerable difficulties in blood grouping or cross-matching; where cold agglutinins were implicated, they were strongly reactive at $18^{\circ} \mathrm{C}$ or above. Careful note was made of the site of the primary tumour, the immunohaematological profile, whether there were any other factors which could have predisposed towards the development of autoantibodies, and whether there was clinically important haemolysis. The latter was ascertained from the clinical and laboratory findings, including haemoglobin concentration and its rate of fall, reticulocyte count, blood and marrow film appearances and measurements of red cell lifespan, serum haptoglobins, bilirubin concentration and lactic dehydrogenase activity. The investigations carried out at this centre included direct antiglobulin tests using agglutination and enzyme linked methods and examination of red cell autoantibodies in serum and eluates; full details have been reported elsewhere. ${ }^{15}$

To determine whether erythrocyte autoantibodies occurred more frequently in patients with carcinoma or whether these were chance associations, ${ }^{2}$ a contingency table was drawn up (table 1) and the data subjected to statistical analysis by the $\chi^{2}$ procedure (with Yates' correction) at 1 degree of freedom ${ }^{6}$; the required significance level was set a priori at $\mathrm{p}<0.05$. Figures for 1988 were used as this was the most recent year for which details of 
Table 1 Contingency table of number of patients referred with erythrocyte autoantibodies and carcinoma in 1988 in Trent region compared with its general population of 4662500

\begin{tabular}{lcc}
\hline & With carcinoma & Without carcinoma \\
\hline $\begin{array}{c}\text { With erythrocyte } \\
\text { autoantibodies }\end{array}$ & 10 & 258 \\
$\begin{array}{c}\text { Without erythrocyte } \\
\text { autoantibodies }\end{array}$ & 13596 & 4648636 \\
\hline
\end{tabular}

the total population and incidence of carcinomas were available; patients with other possible causes for autoantibody development were excluded from the analysis.

\section{Results}

One hundred and sixty patients had both erythrocyte autoantibodies and carcinoma; there were 76 men and 84 women, the mean age ( \pm 1SD) being $67 \cdot 8(11.6)$ years (range 25-92

Table 2 Details of patients with erythrocyte autoantibodies and carcinoma

\begin{tabular}{lcccc}
\hline $\begin{array}{l}\text { Site of primary } \\
\text { tumour }\end{array}$ & $\begin{array}{c}\text { Number of } \\
\text { patients }\end{array}$ & $\begin{array}{c}\text { Males: } \\
\text { females }\end{array}$ & \multicolumn{2}{c}{ Age range in years } \\
(median)
\end{tabular}

Table 3 Serological pattern of erythrocyte autoantibodies in patients with carcinoma and numbers with evidence of haemolysis

\begin{tabular}{llcc}
\hline \multirow{2}{*}{$\begin{array}{l}\text { Site of primary } \\
\text { tumour }\end{array}$} & \multicolumn{2}{c}{$\begin{array}{l}\text { Type of erythrocyte autoantibodies and number of patients (number } \\
\text { with definite or strong evidence of autoimmune haemolysis) }\end{array}$} \\
\cline { 2 - 4 } Breast & Warm & Cold & Mixed \\
\hline Lung & $12(11)$ & $6(4)$ & $2(2)$ \\
Pharyn & $7(6)$ & $7(3)$ & $4(4)$ \\
Oesophagus & $1(0)$ & $0(0)$ & $0(0)$ \\
Stomach & $7(1)$ & $1(0)$ & $0(0)$ \\
Caecum & $9(4)$ & $2\left(2^{\star}\right)$ & $1(1)$ \\
Colon & $1(0)$ & $0(0)$ & $1(1)$ \\
Rectum & $9(3)$ & $5(2)$ & $1(1)$ \\
Liver & $8(7)$ & $5(5)$ & $2(2)$ \\
Pancreas & $1(0)$ & $0(0)$ & $0(0)$ \\
Adrenal & $4(1)$ & $2(2)$ & $1(1)$ \\
Kidney & $0(0)$ & $1(1)$ & $0(0)$ \\
Ureter & $2(0)$ & $0(0)$ & $1(1)$ \\
Bladder & $0(0)$ & $1(0)$ & $0(0)$ \\
Prostate & $6(4)$ & $2(0)$ & $0(0)$ \\
Ovary & $10(5)$ & $3(1)$ & $1(1)$ \\
Uterus & $8(4)$ & $2(0)$ & $0(0)$ \\
Cervix & $2(0)$ & $1(0)$ & $0(0)$ \\
Skin and mucous & $5(0)$ & $3(0)$ & $0(0)$ \\
membranes (squamous & & & \\
cell carcinoma) & $3(1)$ & $1(0)$ & $1(1)$ \\
Breast and colon & $1(0)$ & $0(0)$ & $0(0)$ \\
Unknown & $3(2)$ & $4(2)$ & $0(0)$ \\
Total & $99(49)$ & $46(22)$ & $15(15)$ \\
tolal & &
\end{tabular}

^ In one patient the autoantibody was of Donath-Landsteiner type and showed evidence of specificity within the $\mathrm{P}$ blood group system. years). The analysis of the data in table 1 showed that there was a very highly significant association between erythrocyte autoantibodies and carcinoma $\left(\chi^{2}=97 \cdot 5\right.$; $\mathrm{p}<0.0005$ ).

Table 2 groups the patients according to the site of the primary tumour and gives details of the sex and age distribution. Full histological data were absent in many cases, but 18 subjects were known to have adenocarcinoma, 10 had squamous cell carcinoma, five had poorly differentiated/anaplastic carcinoma, and five had transitional cell carcinoma; similarly, 37 patients were known to have metastatic disease and 28 died within a few months of presentation.

The serological characteristics of the erythrocyte autoantibodies are shown in table 3 , together with the number of patients with evidence of immune mediated haemolysis. The serum haptoglobin concentrations ranged from $<0.1 \mathrm{~g} / 1$ to $5.5 \mathrm{~g} / \mathrm{l}$; of the 86 patients deemed to have haemolysis, haptoglobins were reduced $(<0.4 \mathrm{~g} / 1)$ in 21 , normal $(0.4-1.9 \mathrm{~g} / \mathrm{l})$ in 45 , and raised $(\geqslant 2.0 \mathrm{~g} / \mathrm{l})$ in 20.

Table 4 summarises the findings in 35 patients where other factors predisposing towards autoantibody formation were present.

\section{Discussion}

The results show that erythrocyte autoantibodies and autoimmune haemolysis occur far more frequently in patients with carcinoma than can be accounted for by chance alone $(p<0.0005)$. From the data in table 1 , it is calculated that the two conditions are found together 12-13 times more often than would be expected from their relative frequencies; if patients with other causes for autoantibody development (table 4) had been included, then the figure would be even higher. The data in table 1 are based on certain assumptions as most people "without erythrocyte autoantibodies" were healthy and had not been formally tested. It is felt, however, that the conclusion remains valid as the association would still be significant even if the number of healthy subjects with autoantibodies was six times the 258 quoted. Such an increase would equate with an autoantibody incidence in the general population of about 1 in 3000, which is far higher than in our blood donor or hospital populations. Reports from other institutions suggest that about 1 in 14000 normal people has a positive direct antiglobulin test ${ }^{7}$; the comparable figure for this centre is 1 in 13600 . The large number of patients in the present study allowed the controversy over whether there is a true association between carcinoma and autoantibody formations to be resolved statistically. To the best of our knowledge, this is the most extensive series reported. Previously, evidence for an association had come from single case studies $^{8-29}$ or from those containing only very few patients. ${ }^{30-33}$ It was based on remission of the autoimmune haemolysis with removal of the tumour 1517212628293132 and its relapse with 
Table 4 Patients with erythrocyte autoantibodies and carcinoma: cases with other factors known to predispose towards autoantibody development

\begin{tabular}{|c|c|c|}
\hline $\begin{array}{l}\text { Site of primary } \\
\text { tumour }\end{array}$ & $\begin{array}{l}\text { Type of autoantibody } \\
\text { (number of patients) }\end{array}$ & $\begin{array}{l}\text { Factors other than carcinoma which } \\
\text { may have induced autoantibody } \\
\text { formation (number of patients) }\end{array}$ \\
\hline Breast & Warm (4) & $\begin{array}{l}\text { chronic lymphocytic leukaemia (2) } 2 \dagger ; \\
a \text {-methyl dopa (1) } 1 \dagger ; \text { non-Hodgkin's } \\
\text { lymphoma (1) 1† }\end{array}$ \\
\hline Lung & $\begin{array}{l}\text { Warm (2) } \\
\text { Cold (1) }\end{array}$ & $\begin{array}{l}\text { a-methyl dopa (2) } 2 \dagger \\
\text { chronic cold haemagglutinin disease } \\
\text { (1) } 1 \dagger\end{array}$ \\
\hline Stomach & $\begin{array}{l}\text { Warm (1) } \\
\text { Cold (1‡) }\end{array}$ & $\begin{array}{l}a \text {-methyl dopa (1) 1† } \\
\text { non-Hodgkin's lymphoma (1) } 1 \dagger\end{array}$ \\
\hline Colon & Warm (4) & $\begin{array}{l}\text { a-methyl dopa (3) 1t; chronic } \\
\text { granulocytic leukaemia (1); }\end{array}$ \\
\hline Rectum & $\begin{array}{l}\text { Mixed (1) } \\
\text { Warm (3) }\end{array}$ & $\begin{array}{l}a \text {-methyl dopa (1) } 1 \dagger \\
a \text {-methyl dopa (2) } 2 \dagger ; \text { myelodysplastic } \\
\text { syndrome (1) } 1 \dagger\end{array}$ \\
\hline $\begin{array}{l}\text { Liver } \\
\text { Pancreas } \\
\text { Bladder }\end{array}$ & $\begin{array}{l}\text { Warm (1) } \\
\text { Warm (2) } \\
\text { Warm (3) }\end{array}$ & $\begin{array}{l}a \text {-methyl dopa (1) } \\
a \text {-methyl dopa (2) } 1 \dagger \\
a \text {-methyl dopa (1) it; levodopa (1) } 1+\text {; } \\
\text { chronic lymphocytic leukaemia (1) } 1 \dagger\end{array}$ \\
\hline Prostate & Warm (2) & $\begin{array}{l}\text { chronic lymphocyte leukaemia (1) } 1+\text {; } \\
\text { myelodysplastic syndrome (1) } 1+\end{array}$ \\
\hline Ovary & Warm (2) & $\begin{array}{l}\text { myxoedema (1) } 1 \dagger \text {; ulcerative colitis } \\
\text { (1) } 1 \dagger\end{array}$ \\
\hline $\begin{array}{l}\text { Skin and mucous } \\
\text { membranes } \\
\text { (squamous cell } \\
\text { carcinoma) }\end{array}$ & $\begin{array}{l}\text { Warm (2) } \\
\text { Mixed (1) }\end{array}$ & $\begin{array}{l}a \text {-methyl dopa (1); myxoedema (1) } 1 \dagger \\
\text { autoimmune haemolytic anaemia }{ }^{\star}(1) 1 \dagger\end{array}$ \\
\hline \multirow[t]{2}{*}{$\begin{array}{l}\text { Breast and colon } \\
\text { Unknown }\end{array}$} & $\begin{array}{l}\text { Warm (1) } \\
\text { Warm (2) }\end{array}$ & $\begin{array}{l}\text { myelodysplastic syndrome (1) } \\
\text { myelodysplastic syndrome (1) } 1 \dagger ; \\
\text { autoimmune haemolytic anaemia }\end{array}$ \\
\hline & Cold (2) & $\begin{array}{l}\text { Mycoplasma pneumoniae infection (1) } 1+; \\
\text { systemic lupus erythematosus (1) }\end{array}$ \\
\hline
\end{tabular}

$\dagger$ Number of patients with definite or strong evidence of autoimmune haemolysis 太 Chronic conditions which predated the diagnosis of carcinoma by several years. $\ddagger$ Autoantibody of Donath-Landsteiner type. the appearance of metastases ${ }^{1722} 29$; on specific absorption of autoantibody by lysophilised tumour ${ }^{15}$; on a close temporal relation of onset of both diseases ${ }^{33}$ and on unusual age at presentation. ${ }^{33}$

Red cell autoantibodies were found in patients with a wide variety of carcinomas (table 2); numbers were too small to test statistically whether malignancy of any particular organ or histological type predisposed towards autoantibody formation. The largest groups in table 2 (carcinoma of breast, lung, colon, rectum and prostate) were also among the commonest malignancies in our region (data not shown). From the relative proportions in table 2 and the corresponding Trent regional figures, however, erythrocyte autoantibodies seemed to develop less commonly in patients with lung carcinoma (ratio $0 \cdot 46: 1$ ) and more frequently in those with ovarian carcinoma (ratio 1.9:1). The latter observation is of interest in view of the well recognised association between autoimmune haemolytic anaemia and benign ovarian teratomas. ${ }^{34} 35$ The occurrence of autoimmune haemolytic anaemia in conjunction with carcinomas having widely different primary sites was also evident from previous reports, which featured tumours of lung,,$^{3161824253033}$ ovary, 12212732 cervix, $^{3031}$ stomach, ${ }^{920}$ kidney, ${ }^{1722} 23263132$ caecum, ${ }^{15}$ colon, ${ }^{14} 313336$ uterus, ${ }^{31}$ prostate, ${ }^{13} 31$ larynx, ${ }^{31}$ skin, ${ }^{31}$ breast, ${ }^{11} 2837$ adrenal, ${ }^{33} 38$ bile duct, ${ }^{38}$ bladder/ureter ${ }^{29}$ and parotid gland. ${ }^{33}$ In a few cases the site of the primary tumour could not be established. ${ }^{810}$

It has been suggested that there is a particularly strong association with adenocarcinomas because these tumours secrete mucin-like substances which might have a specific role in inducing autoantibody formation. ${ }^{14}$ Tumour histology was available in only a few of the present cases; nevertheless, numbers were sufficient to show that although autoantibodies were frequently associated with adenocarcinoma, the range of histological types was wide. It should also be remembered that adenocarcinoma is a common type of tumour. These observations are in keeping with previous studies, where although autoimmune haemolytic anaemia was associated with

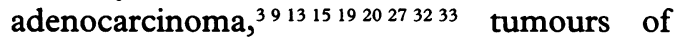
squamous cell, 31824303233 undifferentiated/ anaplastic,,$^{12} 162130$ renal clear cell, ${ }^{172631}$ transitional cell, ${ }^{29}$ and oat cell ${ }^{25} 3132$ types were also well represented.

Eighty six (54\%) patients had evidence of haemolysis (table 3), although confirmation was often difficult because of the effects of haemorrhage, treatment, and blood transfusions. Anaemia also frequently has multiple causes in patients with carcinoma ${ }^{9}$ and an autoimmune component may not be a particular problem in the overall clinical context. Serum haptoglobin measurements are less helpful in these circumstances as they are often increased in malignancy, ${ }^{39}$ and in several of the present patients with obvious haemolysis, normal or raised concentrations were found. The absence of haemolysis in many cases (table 3 ) is not surprising in view of our previous observation that overt red cell destruction is only an extreme manifestation of autoantibody formation. ${ }^{2}$ The publication of so many individual case studies has biased the established findings in favour of patients with active haemolysis, and only a few reports ${ }^{1940}$ have recognised the association of erythrocyte autoantibodies and carcinoma without increased red cell destruction.

The tumour was known to have spread in 37 of our patients, suggesting that erythrocyte autoantibodies tended to occur where there was a large tumour mass and metastatic disease. As would be expected, these findings indicated a poor prognosis and 28 patients died within a few months of presentation. Data were incomplete and the true figures were almost certainly much higher. Similar observations regarding the association with

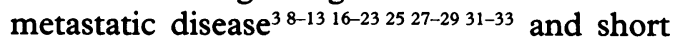

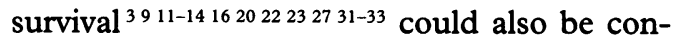
cluded from previous reports. However, in a few patients with $^{21}$ or without metastases, ${ }^{32}$ appropriate treatment resulted in cessation of haemolysis and long survival.

All serological types of autoantibody were found (table 3) and the ratio of warm: cold:mixed types $(7: 3: 1)$ was similar to the 9:4:1 found, overall, in a large series of patients with autoimmune haemolysis. ${ }^{2}$ The patient groups were too small to determine whether the different serological types were associated with any particular carcinoma. Details of autoantibody type were not always given in previous publications, but warm ${ }^{16} 1822-242732$ and cold 1721252633 types were found in patients with carcinoma of lung, ${ }^{161824253233}$ ovary, ${ }^{21} 2732$ kidney, ${ }^{1722232632}$ and bile duct. ${ }^{38}$ Warm autoantibodies were noted in patients with carcinoma of the 
stomach, ${ }^{20}$ caecum, ${ }^{15}$ and breast, ${ }^{28} 37$ and cold autoantibodies were found in patients with carcinoma of the colon, ${ }^{33}$ adrenal, ${ }^{33} 38$ prostate, ${ }^{13}$ and parotid gland. ${ }^{33}$ Mixed warm and cold autoantibodies were described in a patient with carcinoma of the bladder/ureter, ${ }^{29}$ and in a patient with carcinoma of the colon autoimmune haemolysis was due to polyagglutination of the Th type. ${ }^{36}$ The report of a patient with oat cell carcinoma of the lung and atypical paroxysmal cold haemoglobinuria $^{24}$ was of interest in view of our patient with Donath-Landsteiner antibodies (tables 3 and 4); in the former case, however, ${ }^{24}$ the biphasic haemolysins had anti-I specificity and were of IgM class.

Possible causes for the autoantibody development, other than carcinoma, were recognised in 35 patients (table 4). We were initially surprised that $a$-methyl dopa treatment was the most common (found in 15 cases), rather than lymphoid neoplasia as noted previously. ${ }^{31}$ However, most of our patients were elderly (mean age 67.8 years) and belonged to a generation in which $a$-methyl dopa, a potent inducer of red cell autoantibodies, was widely prescribed.

Several proposals for the mechanism of autoantibody production in patients with carcinoma have been made: (i) the tumour modifies red cell antigens so that an autoantibody response is elicited ${ }^{151920}$; (ii) the autoantibodies are formed against tumour antigens and cross-react with the erythrocytes 151820222829 ; (iii) the carcinoma produces the red cell autoantibodies 152022 28; (iv) immune complexes, formed between tumour associated antigens and antibodies, bind to the red cells and cause haemolysis through the action of complement $^{2022} ;(\mathrm{v})$ immune dysfunction in patients with carcinoma results in forbidden clones of lymphocytes frequently escaping surveillance, but these are only recognised when they have clinical consequences such as autoimmune haemolysis ${ }^{1631}$; and (vi) there is a failure of immune homeostasis which permits both tumour growth and autoantibody production. The different theories are not mutually exclusive and, no doubt, more than one may be operative in a particular patient. We have long regarded erythrocyte autoantibody formation and autoimmune haemolysis as reflecting a fundamental disturbance in immune homeostasis, ${ }^{1}$ and it is of interest that carcinoma developed in three of our patients with autoimmune haemolytic anaemia (table 4); a similar occurrence was noted in two $^{2031}$ out of 34 others $^{3911-33}$ where these conditions were associated.

We thank the Statistical Information Unit and Mrs I Ainsworth (Cancer Registration Bureau) at the Trent Regional Health Authority for providing, respectively, population details and carcinoma incidence figures. We also thank Mrs M E Grayson for secretarial assistance.

1 Sokol RJ, Hewitt S, Stamps BK. Autoimmune haemolysis: an 18 year study of 865 cases referred to a regional trans-

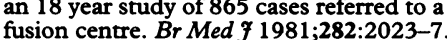

2 Sokol RJ, Booker DJ, Stamps R. The pathology of autoimmune haemolytic anaemia. If Clin Pathol 1992;45: 1047-52.

3 Najafi JA, Guzman LG. Tumor induced autoimmune hemolytic anemia in bronchogenic carcinoma: case reports. Milit Med 1979;144:754-6.
4 Rassam JW, Anderson G. Incidence of paramalignant disorders in bronchogenic carcinoma. Thorax 1975;30: 86-90.

5 Sokol RJ, Hewitt S, Booker DJ, Bailey A. Erythrocyte autoantibodies, subclasses of IgG and autoimmune haemolysis. Autoimmunity 1990;6:99-104.

6 Mack C. Essentials of statistics for scientists and technologists. New York: Plenum Press, 1967.

7 Gorst DW, Rawlinson VI, Merry AH, Stratton F. Positive direct antiglobulin test in normal individuals. Vox Sang 1980;38:99-105.

8 Jordan WS, Dingle JH. Coombs titer variations in acquired hemolytic anemia. $f$ Lab Clin Med 1949;34:1614-15.

9 Frumin AM, Mendell TH, Meranze DR. Hematologic manifestations of metastat

10 Johnston GAW. Red cell lifespan in carcinomatosis. Med $\mathcal{F}$ Aust 1956;1:736-8.

11 Sohier WD, Juranies E, Aub JC. Hemolytic anemia, a host response to malignancy. Cancer Res 1957;17:767-74.

12 Yam LT, Rudzki C, Busch S, Leithold SL. Ovarian neoplasm associated with autoimmune hemolytic anemia. Am f Obstet Gynecol 1966;95:207-11.

13 Soltoft J, Lind K. The cold haemagglutinin syndrome and carcinoma of the prostate. Acta Pathol Microbiol Scand 1968;73:13-18.

14 Miura AB, Shibata A, Akihama $T$, et al. Autoimmune hemolytic anemia associated with colon cancer. Cancer 1974;33:111-14.

15 Gordon PA, Baylis PH, Bird GWG. Tumour-induced autoimmune haemolytic anaemia. $\mathrm{Br} M e d \quad \mathcal{f} 1976$;i: 1569-70.

16 Horne MK, McAnally TP. Hemolytic anemia with lung carcinoma: case reports. Milit Med 1978;143:188-9.

17 Bradley GW, Harvey M. Haemolytic anaemia with hypernephroma. Postgrad Med f 1981;57:46-7.

18 Cooper R, Tappin JA, Deveshevar S. Bronchial carcinoma presenting as autoimmune haemolytic anaemia. Postgrad Med $\mathcal{F} 1981 ; 57: 528-9$.

19 Castella A, LaBarge BP, Lauenstein KJ, Davey FR. Autoanti- $A_{1}$ antibody in a patient with metastatic adenocarcinoma. Transfusion 1983;23:339-41.

20 Inoue $\mathrm{Y}, \mathrm{Kaku} \mathrm{K}$, Kaneko T, Matsumoto N. Autoimmune hemolytic anemia and gastric cancer: case report and review of the literature. Acta Haematol fpn 1983;46: review $36-41$.

21 Carreras Vescio LA, Toblli JE, Rey JA, Assaf ME, de Maria $\mathrm{HE}$, et al. Autoimmune hemolytic anemia associated with an ovarian neoplasm. Medicina 1983;43: 415-24.

22 Johnson P, Gualtieri RJ, Mohler DN, Carpenter JT. Autoimmune hemolytic anemia associated with a hypernephroma. South Med f 1985;75:1129-31.

23 Venzano C, de Micheli A, Cavallero GB. Autoimmune hemolytic anemia associated with hypernephroma. Haematologica 1985;70:59-61.

24 Honan W, Balazs J, Jariwalla AG. Autoimmune haemolytic anaemia (AHA) and lung carcinoma. Br 7 Clin Pract 1986;40:35-6.

25 Lippman SM, Winn L, Grumet FC, Levitt LJ. Evans' syndrome as a presenting manifestation of atypical paroxysmal cold hemoglobinuria. Am $\mathcal{f}$ Med 1987;82:1065-72.

26 Girelli G, Adorno G, Perrone MP, et al. Kidney carcinoma revealed by autoimmune hemolytic anemia. Haematologica 1988;73:309-11.

27 Tsuda A, Iwabuchi A, Yaguchi M, et al. The first case of autoimmune hemolytic anemia in a patient with ovarian carcinoma in Japan. Rinsho Ketsueki 1988;29:227-31.

28 Adorno G, Girelli G, Perrone MP, et al. A metastatic breast carcinoma presenting as autoimmune hemolytic breast carcinoma presenting as

29 Hibino S, Stoller RG, Jacobs SA. Autoimmune haemolytic anaemia associated with transitional cell carcinoma. Lancet 1992;340:373.

30 Ellis LD, Westerman MP. Autoimmune hemolytic anemia and cancer. $\mathscr{F} A M A$ 1965;193:190-2.

31 Pirofsky B. Autoimmunization and the autoimmune hemolytic anemias. Baltimore: Williams \& Wilkins, 1969.

32 Spira MA, Lynch EC. Autoimmune hemolytic anemia and carcinoma: an unusual association. $A m f$ Med 1979;67: 753-8.

33 Wortman J, Rosse W, Logue G. Cold agglutinin autoim mune hemolytic anemia in nonhematologic malignancies. Am $千$ Hematol 1979;6:275-83.

34 Payne D, Muss HB, Homesley HD, Jobson VW, Baird FG. Autoimmune hemolytic anemia and ovarian dermoid cysts: case report and review of literature. Cancer 1981;48:721-4.

35 Murad MD, Mohler DN, Carpenter JT. Remission of immune hemolytic anemia after removal of ovarian dermoid cyst: case report. VA Med 1982;109:187-90.

36 Levene NA, Levene C, Gekker K, Sigler E, Merhar H Berrebi A. Th polyagglutination with fatal outcome in a patient with massive intravascular haemolysis and perforated tumour of colon. Am $\mathcal{H}$ Hematol 1990;35:127-8.

37 Worlledge S. Immune haemolytic anaemias. In: Hardisty RM, Weatherall DJ, eds. Blood and its disorders. Oxford: RM, Weatherall DJ, eds. Blood and its disorders.

38 Sokol RI, Hewitt S. Autoimmune hemolysis and nonovarian carcinomas. South Med F 1986;79:1466.

39 Javid J. Human serum haptoglobins: a brief review. Semin Hematol 1967;4:35-52.

40 West CD, Ley AB, Pearson OH. Myelophthisic anemia in cancer of the breast. $A m \mathcal{F}$ Med 1955;18:923-31. 